"Impact of FDI inflow, crude oil prices, and economic growth on $\mathrm{CO} 2$ emission in Tunisia: Symmetric and asymmetric analysis through ARDL and NARDL approach"

\begin{tabular}{|c|c|}
\hline AUTHORS & Tarek Ghazouani (D https://orcid.org/0000-0001-5879-100X \\
\hline ARTICLE INFO & $\begin{array}{l}\text { Tarek Ghazouani (2021). Impact of FDI inflow, crude oil prices, and economic } \\
\text { growth on CO2 emission in Tunisia: Symmetric and asymmetric analysis through } \\
\text { ARDL and NARDL approach. Environmental Economics, 12(1), 1-13. } \\
\text { doi:10.21511/ee.12(1).2021.01 }\end{array}$ \\
\hline DOI & http://dx.doi.org/10.21511/ee.12(1).2021.01 \\
\hline RELEASED ON & Thursday, 14 January 2021 \\
\hline RECEIVED ON & Wednesday, 02 December 2020 \\
\hline ACCEPTED ON & Tuesday, 12 January 2021 \\
\hline & $((c))_{E Y}$ \\
\hline LICENSE & $\begin{array}{l}\text { This work is licensed under a Creative Commons Attribution } 4.0 \text { International } \\
\text { License }\end{array}$ \\
\hline JOURNAL & "Environmental Economics" \\
\hline ISSN PRINT & $1998-6041$ \\
\hline ISSN ONLINE & $1998-605 X$ \\
\hline PUBLISHER & LLC "Consulting Publishing Company "Business Perspectives" \\
\hline FOUNDER & LLC “Consulting Publishing Company "Business Perspectives" \\
\hline$\sigma^{0}$ & 三:= \\
\hline NUMBER OF REFERENCES & NUMBER OF FIGURES \\
\hline 49 & 10 \\
\hline
\end{tabular}

(c) The author(s) 2023. This publication is an open access article. 


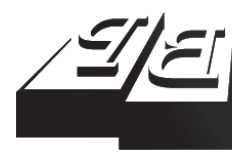

BUSINESS PERSPECTIVES

(0)

LLC "CPC "Business Perspectives" Hryhorii Skovoroda lane, 10, Sumy, 40022, Ukraine www.businessperspectives.org
Received on: $2^{\text {nd }}$ of December, 2020 Accepted on: $12^{\text {th }}$ of January, 2021 Published on: $14^{\text {th }}$ of January, 2021

(c) Tarek Ghazouani, 2021

Tarek Ghazouani, Ph.D, Faculty of Law, Economics and Management of Jendouba University of Jendouba, Tunisia.

\section{IMPACT OF FDI INFLOW, CRUDE OIL PRICES, AND ECONOMIC GROWTH ON CO2 EMISSION IN TUNISIA: SYMMETRIC AND ASYMMETRIC ANALYSIS THROUGH ARDL AND NARDL APPROACH}

\begin{abstract}
This study explores the symmetric and asymmetric impact of real GDP per capita, FDI inflow, and crude oil price on CO2 emission in Tunisia for the 1972-2016 period. Using the cointegration tests, namely ARDL and NARDL bound test, the results show that the variables are associated in a long run relationship. Long run estimates from both approach confirms the validity of ECK hypothesis for Tunisia. Symmetric analysis reveals that economic growth and the price of crude oil adversely affect the environment, in contrast to FDI inflows that reduce $\mathrm{CO} 2$ emissions in the long run. Whereas the asymmetric analysis show that increase in crude oil price harm the environment and decrease in crude oil price have positive repercussions on the environment. The causality analysis suggests that a bilateral link exists between economic growth and carbon emissions and a one-way causality ranges from FDI inflows and crude oil prices to carbon emissions. Thus, some policy recommendations have been formulated to help Tunisia reduce carbon emissions and support economic development.
\end{abstract}

Keywords

JEL Classification FDI inflow, crude oil prices, economic growth, $\mathrm{CO} 2$ emission, ARDL, NARDL, Tunisia

\section{INTRODUCTION}

Climate change is among the greatest challenges facing humanity. It affects all countries and can have devastating effects on communities and individuals. Therefore, the achievement of sustainable development and the abatement of global warming have challenged academics and decision-makers to focus on the drivers of $\mathrm{CO} 2$ emissions, in order to develop the measures and policies needed to improve environmental quality. The situation becomes even worse when it comes to promoting economic growth, since energy is an important determinant in achieving such a goal (Stern, 2011). The environmental impact of economic growth is based on a controversial assumption, provided by Grossman and Krueger (1991) which so-called EKC (Environmental Kuznets Curve). It stipulates an inverted U-shaped link between level of development and emissions whereby a national pollution concentration increases as the economy develops to a certain level where it decreases again as the country uses its increased affluence to further reduce pollution concentrations.

Similarly, given its role as a driver of economic growth, FDI inflows could be detrimental to the environment of host countries, general- 
ly developing countries, where foreign firms producing polluting goods would seek to locate in those countries with comparatively weak environmental regulations compared to their countries of origin with environmental requirements. However, the environmental consequences of FDI flows can be asymmetric, as the massive of FDI inflows does not necessarily have the same sign and magnitude of effect as the sudden stop of FDI flows.

As Keynes (1936) states, the trend up-wards of any macroeconomic variable transforms unexpectedly towards a negative trend, while a falling trend does not have the same abrupt turn towards an up-trend. Assuming that increased FDI flows generate $\mathrm{CO} 2$ emissions through increased energy consumption, however, it may have the same effect with their decrease. Shahbaz et al. (2014) attribute this impact to the "ratchet effect" whereby energy consumption increases despite the fall in income caused by sudden stop in capital flows. In addition, it may be that as a result of sudden reversals in FDI, domestic investment booms in response to domestic demand, leading in turn to increased energy consumption, which increases $\mathrm{CO} 2$ emissions. In this respect, it is crucial to examine the possible asymmetry of the environmental consequences of FDI flows in order to avoid inappropriate policies recommendations.

Building on the environmental and economic concerns, this study explores the symmetrical and asymmetrical connection between economic growth and $\mathrm{CO} 2$ emissions with the incorporation of crude oil prices and FDI inflows within the emissions function of the Tunisian economy. From an ecological view, the crude oil price could indirectly affect energy use and environmental quality via its impact on these factors. Indeed, two scenarios can occur and this depends on whether the country is a net oil-exporting or importing economies. According to Sturm et al. (2009), oil-exporting countries will increase their economic activity as a result of the surge in their income following the rise in the price of crude oil. Based on this idea, Nwani (2017) indicates that increase economic activity requires more energy which means additional carbon emissions. However, for oil-importing countries, any drop in crude oil prices could reduce their incentive to invest in environment-friendly energies and increase their use of fossil fuel energy, thus contributing to $\mathrm{CO} 2$ emissions. Therefore, considered as a semi-exporter country, Tunisia is characterized by a strong vulnerability of the national economy to the volatility of international energy prices. Thus, this can change its behavior in terms of energy consumption, which will ultimately reflect on the environment.

To the best of our knowledge, the symmetric and asymmetric impact of oil crude price along with FDI inflows on $\mathrm{CO} 2$ emissions in Tunisia has not been earlier explored. Aiming to fill this void, this study conducts an in-depth examination of the impact of economic growth, FDI inflows, and crude oil prices on Tunisia's CO2 emissions using advanced econometric methods. Firstly, the linear ARDL (Autoregressive Distributed Lag) was implemented to investigate the symmetric short- and long-run association among candidate variables. While, the non-linear ARDL (NARDL) by Shin et al. (2014) has used to explore this association asymmetrically, as to assess effects of both positive and negative changes in FDI inflows and crude oil price on Tunisian's $\mathrm{CO} 2$ emissions, respectively. Finally, the block exogeneity Wald test has employed to analyze the directional causality among candidate variable.

\section{LITERATURE REVIEW}

There are a substantial number of empirical investigations dealing with the environmental consequences of economic growth by analyzing them through the EKC assumption (see Shahbaz and Sinha (2019) for a literature survey). However, among these studies, there are those that support this EKC assumption (Apergis \& Ozturk, 2015;
Bölük \& Mert, 2015; Baek, 2016; Pata, 2018; Usman et al., 2019; Malik et al., 2020), while other papers do not (Apergis, 2016; Kang et al., 2016; Balsalobre et al., 2015; Adu \& Denkyirah, 2019). The contradictory results given are often explained either by differences in a country's level of development (Apergis, 2016) or by differences in the additional variables included in the emission function model (Amri, 2018). Likewise, in the case of Tunisia, the 
validity of the EKC assumption is evenly disputed, as Ben Jebli and Ben Youssef (2015), Farhani and Ozturk (2015), and Amri $(2017,2018)$ reject the EKC hypothesis. In contrast, Shahbaz et al. (2014), Kwakwa et al. (2018), and Mahmood et al. (2019) proved the existence of EKC in Tunisian economy. Kwakwa et al. (2018) concluded that the occurrence of an inverted U-curve depends on sources of $\mathrm{CO} 2$ emissions in Tunisia.

Regarding the relationship between FDI inflows and the environment degradation, evidence remains also unclear. Some evidence found that FDI inflows affect positively $\mathrm{CO} 2$ emissions (for instance, Al-Mulali, 2012; Omri et al., 2014; Haug \& Ucal, 2019; Malik et al., 2020; Essandoh et al., 2020). Closely, this category of studies supports the famous "pollution haven hypothesis" according to which developing countries suffer more from environmental pollution caused by multinational companies that transfer high-pollution industries (Copeland \& Taylor, 1994). Conversely, other evidence have found that FDI inflows affect negatively CO2 emissions (such as Al-Mulali \& Tang, 2013; Sung et al., 2018; Jiang et al., 2018). Consequently, this group of studies supports the known "pollution halo hypothesis", which postulates that multinational companies disseminate their clean technologies to host countries through the transfer of innovative technologies. However, there are also other studies arguing that FDI inflows does not detrimental to the environment (Lee, 2013; Chandran \& Tang, 2013). Similarly for Tunisia, there are mixed results regarding the relationship between these two variables, as Hakimi and Hamdi (2016) prove a positive impact of FDI flows on pollution while Abdouli and Hammami (2016) show an insignificant negative impact.

As for the crude oil prices- $\mathrm{CO} 2$ emissions nexus, although the existence of a few empirical studies, the evidence also seems varied. Some studies reveal that a rise in crude oil prices leads to increase in energy consumption which in turn causes higher $\mathrm{CO} 2$ emission. For instance, Nwani (2017) find that the crude oil price, energy consumption, and other economic performance indicators are cointegrated in a long-run relationship with $\mathrm{CO} 2$ emissions in the Ecuadorian for the period 1971-2013. Further, he reveals that the price of crude oil positively and significantly affects en- ergy use and carbon dioxide emissions in both the short and long run. The same findings were obtained by Agbanike et al. (2019) when exploring this relationship for the Venezuela. Contrarily, other studies have found that rising crude oil prices have a positive influence on the environment (Mensah et al., 2019; Malik et al., 2020). Here, the results found are explained by the fact whether an oil-exporting or oil-importing economy. For net oil-importing economies, a drop in crude oil price means an over-use of energy and this is reflected in higher $\mathrm{CO} 2$ emissions and the other way round (Vielle \& Viguier, 2007). While for oil-exporting economies, higher crude oil prices would lead to higher incomes, which would increase the energy consumption generated by more economic activities, thus causing more $\mathrm{CO} 2$ emissions, which in turn worsens the quality of the environment and vice versa (Sturm et al., 2009; Nwani, 2017).

\section{DATA AND METHODOLOGY}

\subsection{Data and empirical model}

The data adopted in the present paper is based on 46 observations for Tunisia spanning the period 1972-2016. Data includes CO2 emissions as an indicator of environmental deterioration expressed in metric tons per-capita, GDP per-capita (in constant 2010 USD), the net inflow of FDI per-capita (in constant 2010 USD), which were collected from Word Bank Indicators. In addition, they include crude oil price (in USD per-barrel), which was extracted from BP Statistical Review.

To assess the environmental effect of FDI inflows, crude oil prices and economic growth in Tunisia, the following specific model has been implemented:

$$
\begin{aligned}
& \ln C_{t}=\beta_{0}+\beta_{1}\left(\ln G D P_{t}\right)+\beta_{2}\left(\ln G D P_{t}^{2}\right)+ \\
& +\beta_{3}\left(\ln F D I_{t}\right)+\beta_{3}\left(\ln O I P_{t}\right)+\mu_{t},
\end{aligned}
$$

where

$\ln C_{t}, \ln G D P_{t}, \ln G D P_{t}^{2}, \ln F D I_{t}$, and $\ln O I P_{t}$ , are the natural logarithms of $\mathrm{CO}_{2}$ emissions per-capita, GDP per-capita, the square term of GDP per-capita, FDI per-capita and crude oil prices, respectively. The square of real GDP per-capita $\left(\ln G D P_{t}^{2}\right)$ is included in equation 1 to implement 
EKC hypothesis augmented by FDI inflows and crude oil price. $\mu_{t}$ and $t$ refer to the residual term and the year, respectively.

\subsection{The symmetric analysis}

To examine the symmetric association among FDI inflows, crude oil price, economic growth, and $\mathrm{CO} 2$ emissions, the paper apply the Pesaran et al.'s (2001) cointegration test, namely ARDL test. Characterized by its advantages, when compared to other conventional cointegration methods, the ARDL approach has become very popular amidst scientists in recently years (for instance, Nwani, 2017; Agbanike et al., 2019; Malik et al., 2020). Before implementing the ARDL model, whether linear or non-linear, the order of integration of variables must be identified. For this purpose, some conventional unit root tests are used, such as the ADF-test by Dickey-Fuller and the PP-test by Phillips-Perron, along with the LM-test by Lee and Strazicich (2003) to take into account for possible structural breaks in the series. Next step consist to assess the evidence of a long run association by conducting the F-test. The empirical expression of the ARDL bound test for cointegration is presented as follows:

$$
\begin{aligned}
& \Delta \ln C_{t}=\alpha+\beta_{1} \ln C_{t-1}+\beta_{2} \ln G D P_{t-1}+ \\
& +\beta_{3} \ln G D P_{t-1}^{2}+\beta_{4} \ln F D I_{t-1}+\beta_{5} \ln O I P_{t-1}+ \\
& +\sum_{i=1}^{n} \varphi_{1} \Delta \ln C_{t-i}+\sum_{i=0}^{m} \varphi_{2} \Delta \ln G D P_{t-i}+ \\
& +\sum_{i=0}^{m} \varphi_{3} \Delta \ln G D P_{t-1}^{2}+\sum_{i=0}^{m} \varphi_{4} \Delta \ln F D I_{t-i}+ \\
& +\sum_{i=0}^{m} \varphi_{5} \Delta \ln O I P_{t-i}+\varepsilon_{t}
\end{aligned}
$$

where $n$ and $m$ are the lag length obtained using SCI (Schwarz Information Criteria), and $\varepsilon_{t}$ indicates the white nose error term. While $\beta_{1}$ to $\beta_{5}$ and $\varphi_{2}$ to $\varphi_{5}$ represent the long- and short-run dynamic, respectively. The existence or not of a cointegrating relationship is based on the F-test. The null hypothesis $\left(\beta_{1}=\beta_{2}=\beta_{3}=\beta_{4}=\beta_{5}=0\right)$ is tested through Wald test based on F-statistics to verify whether there is cointegration or not. The compared F-statistics to the lower and the upper bound critical value would conclude the existence of cointegration or not. Afterwards, the long- and short-run estimation will be performed if the cointegration relationship has been confirmed. The short-run model is presented by equation (3) below in which the parameter $\delta_{i}$ reflects the longterm equilibrium adjustment speed after a shortterm occurred event.

$$
\begin{aligned}
& \Delta \ln C_{t}=\alpha+\delta_{i} E C M_{t-1}+ \\
& +\sum_{i=1}^{n} \varphi_{1} \Delta \ln C_{t-i}+\sum_{i=0}^{m} \varphi_{2} \Delta \ln G D P_{t-i}+ \\
& +\sum_{i=0}^{m} \varphi_{3} \Delta \ln G D P_{t-1}^{2}+\sum_{i=0}^{m} \varphi_{4} \Delta \ln F D I_{t-i}+ \\
& +\sum_{i=0}^{m} \varphi_{5} \Delta \ln O I P_{t-i}+\varepsilon_{t}
\end{aligned}
$$

\subsection{The asymmetric analysis}

Since it is ignored by the linear ARDL model, this paper uses the procedure of Shin et al. (2014) to determine the possible asymmetric association by conducting the NARDL model. Indeed, the NARDL model exhibits the same requirements for the integration order of the variables as the ARDL model. Thus, following Shin et al. (2014), equation 2 can be restated in the following form:

$$
\begin{aligned}
& \Delta \ln C_{t}=\alpha+\beta_{1} \ln C_{t-1}+\beta_{2} \ln G D P_{t-1}+ \\
& +\beta_{3} \ln G D P_{t-1}^{2}+\beta_{4}^{+} \ln F D I_{t-1}^{+}+\beta_{5}^{-} \ln F D I_{t-1}^{-}+ \\
& +\beta_{6}^{+} \ln O I P_{t-1}^{+}+\beta_{7}^{-} \ln O I P_{t-1}^{-}+\sum_{i=1}^{n} \theta_{i} \Delta \ln C_{t-i}+ \\
& +\sum_{i=0}^{m} \theta_{i} \Delta \ln G D P_{t-i}+\sum_{i=0}^{m} \theta_{i} \Delta \ln G D P_{t-1}^{2}+ \\
& +\sum_{i=0}^{m}\left(\theta_{i}^{+} \Delta \ln F D I_{t-i}^{+}+\theta_{i}^{-} \Delta \ln F D I_{t-i}^{-}\right)+
\end{aligned}
$$

$+\sum_{i=0}^{m}\left(\theta_{i}^{+} \Delta \ln O I P_{t-i}^{+}+\theta_{i}^{-} \Delta \ln O I P_{t-i}^{-}\right)+\varepsilon_{t}$.

From equation (4), $\beta_{i}^{+}\left(\sum_{i}^{m} \theta_{i}^{+}\right)$and $\beta_{i}^{-}\left(\sum^{m} \theta_{i}^{-}\right)$
captures the long (short) impact of FDI and crude $\mathrm{OIP}_{t}$ on $C_{t}$. As for ARDL model, the bound test is resorted to determine whether the variables are asymmetrically co-integrated or not. In addition, the Wald-test is called to assess the long (short) run symmetric linkage $\beta$ $=\beta^{+}=\beta^{-}\left(\theta=\theta^{+}=\theta^{-}\right)$for FDI and OIP. Given the 
validation of the non-linear relationship, the short run asymmetric association can be provided via the dynamic multiplier effect in the following way:

$D_{s}^{+}=\sum_{j=0}^{s} \frac{\omega \ln C_{t-j}}{\omega \ln F D I_{t-i}^{+}}$,

$D_{s}^{-}=\sum_{j=0}^{s} \frac{\omega \ln C_{t-j}}{\omega \ln F D I_{t-i}^{-}}$,

$s=0,1,2,3, \ldots$.

....Noting that $s \rightarrow \infty, D_{s}^{+} \rightarrow \beta_{4}^{+}, D_{s}^{-} \rightarrow \beta_{5}^{-}$,

$D_{s}^{+}=\sum_{j=0}^{s} \frac{\omega \ln C_{t-j}}{\omega \ln O I P_{t-i}^{+}}$,

$D_{s}^{-}=\sum_{j=0}^{s} \frac{\omega \ln C_{t-j}}{\omega \ln O I P_{t-i}^{-}}$,

$s=0,1,2,3, \ldots$.

...Noting that $s \rightarrow \infty, D_{s}^{+} \rightarrow \beta_{6}^{+}, D_{s}^{-} \rightarrow \beta_{7}^{-}$.

\section{EMPIRICAL RESULTS AND DISCUSSION}

\subsection{The symmetric analysis results}

Checking the stationarity of the series is a prerequisite for deciding which cointegration test to choose. Using the ADF and PP tests, the empirical outcome in Table 1 shows that some variables are integrated in level, that is $\mathrm{I}(0)$ and other after the first difference, that is I(1), while, when using the LS test which take into account for possible structural breaks, all variables are integrated in same order, that is I(1). Therefore, altogether, these results allow us to apply the ARDL cointegration approach. The result of the cointegration test presented in Table 2 shows a F-stat value (10.327) exceeding the critical value of the upper bound of Narayan (2005) table at $1 \%$ level, which confirm the existence of cointegration among studied variables.

The implementation of co-integration across variables leads us to assess the short and long run impact of GDP, FDI and OIP on carbon emissions (C). Tables 3 and 4 outline that economic growth affects significantly and positively $\mathrm{CO} 2$ emissions in the long run. While, the quadratic term of real GDP per capita improve significantly the environment, which leads us to conclude that the inverted U-shaped EKC for Tunisia stands only on long run with a turn point equal to $4,590.126$ USD per capita. The validation of the EKC assumption corroborates the findings by Shahbaz et al. (2014) and Mahmood et al. (2019). The coefficient of ECT(-1) is statistically significant and negative indicating that around $56 \%$ of the short-term unbalance rectified in the long term.

Table 2. F-Bound test for linear cointegration $\operatorname{ARDL}(1,0,0,3,4)$

\begin{tabular}{|c|c|c|c|c|}
\hline \multirow{2}{*}{\multicolumn{2}{|c|}{$\begin{array}{l}\text { F-Bounds Test } \\
\text { Significance }\end{array}$}} & \multicolumn{3}{|c|}{$\begin{array}{c}\text { Null hypothesis: No levels } \\
\text { relationship }\end{array}$} \\
\hline & & $I(0)$ & $I(1)$ & \\
\hline \multirow{2}{*}{ F-statistic } & \multirow{2}{*}{10.327} & $10 \%$ & 2.2 & 3.09 \\
\hline & & $5 \%$ & 2.52 & 3.49 \\
\hline \multirow{2}{*}{ k } & \multirow{2}{*}{4} & $2.5 \%$ & 2.82 & 3.87 \\
\hline & & $1 \%$ & 3.29 & 4.37 \\
\hline
\end{tabular}

The crude oil price affects $\mathrm{CO} 2$ emissions positively and significantly at $1 \%$ level, as the results show

Table 1. Unit root test

\begin{tabular}{|c|c|c|c|c|}
\hline Tests & ADF & PP & \multicolumn{2}{|c|}{ LS } \\
\hline Variables & T-statistic & T-statistic & T-statistic & $\mathrm{TB}_{1}, \mathrm{~TB}_{2}$ \\
\hline C & -2.498 & -2.737 & -2.262 & 1982, 1991 \\
\hline$\Delta C$ & $-8.547 *$ & $-8.396^{*}$ & $-6.890 *$ & 1981,1988 \\
\hline$G D P$ & -1.464 & -1.516 & -3.306 & 1978,1995 \\
\hline$\triangle \mathrm{GDP}$ & $-9.215^{*}$ & $-8.819 *$ & $-6.272 * *$ & 1989,2009 \\
\hline$G D P^{2}$ & -1.206 & -1.234 & -3.176 & 1978,1995 \\
\hline$\triangle G D P^{2}$ & $-8.851^{*}$ & $-8.524^{*}$ & $-6.990 * *$ & 1989,2009 \\
\hline$F D I$ & $-2.878 * * *$ & $-2.779 * * *$ & -5.466 & 1982,2006 \\
\hline$\triangle F D I$ & $-8.938^{*}$ & $-18.863^{*}$ & $-7.280^{*}$ & 2004,2009 \\
\hline OIP & $-3.031 * *$ & $-3.037 * *$ & -4.738 & 1983,2003 \\
\hline$\triangle O I P$ & $-5.905^{*}$ & $-5.906^{*}$ & $-7.599 *$ & 1985,2003 \\
\hline
\end{tabular}

Note: $*, * * * * *$ indicates that value is significant at 1,5 , and $10 \%$ threshold, respectively. TB indicates time break. 
that a $1 \%$ increase in the OIP is liable to lead to an increment of around $0.027 \%$ in $\mathrm{CO} 2$ emissions in the Tunisian economy. This positive impact exerted by crude oil price on $\mathrm{CO} 2$ emissions might be explained through two mechanisms. Firstly, the income generated by crude oil export revenues and the tax revenues of the oil companies provide economic conditions that produce more energy consumption. Indeed, considered as semi oil-dependent economy, in 2018, Tunisia exported USD 614 million of crude oil, making it the 50th largest crude oil exporter in the world (Energy Information Administration). In the same year, crude oil was the 5th most exported product in Tunisia. The oil revenue average value was 5.38 per cent of GDP during the period from 1970 to 2018 (World Bank Indicator, 2019).

In addition, and according to the Central Bank of Tunisia report (2017), the tax revenue of oil companies constitutes about $40 \%$ of total direct taxes, thus improving the country total income. In this respect, the rise in crude oil prices contributes to economic growth in Tunisia, which in turn generates more economic activity, particularly in energy-intensive sectors. Brini et al. (2017) reveal that a $1 \%$ increment in the oil price increases Tunisia's economic growth by $1.175 \%$. Secondly, the subsidization of energy consumption encourages more energy use. The rise in the price of a barrel of oil leads to additional costs for economic institutions, which pushes countries to subsidy energy consumption. A study conducted by the International Monetary Fund has shown that the percentage of subsidies for fuel amounted to $13.7 \%$ of the state budget in 2013. This study also revealed that the fuel subsidy policy in Tunisia leads to excessive energy consumption and a reduction in investment incentives in the field of rationalization of consumption and renewable energies.

FDI significantly and negatively affects carbon emissions in the long run at the level of 5\%, which leads to accept the presence of the halo hypothesis. This might explain the contribution of FDI to the reduction of emissions by the fact that investors, when they enter Tunisia, tend to respect environmental regulations and international standards. In addition, this can suggest that FDI inflow contributes to the transfer of clean technologies which lead to improve energy efficiency and the reduction of greenhouse gas emissions. This finding is in accordance with the evidence of Zhang and Zhou (2016) for the Chinese economy.

Table 3 documents also the diagnostic analysis (lower part), were the Jarque \& Bera-test and Breusch \& Godfrey L-M-test suggest normality and absence of serial correlation in the model, respectively, while the ARCH-test and BreuschPagan-Godfrey heteroscedasticity test accept the alternate hypothesis of heteroscedasticity. In addi-

Table 3. Linear ARDL model long-run results

\begin{tabular}{|c|c|c|c|}
\hline \multicolumn{4}{|c|}{ Dependent variable: $C_{t}$} \\
\hline Variable & Coefficient & St. error & T-stat \\
\hline$G D P_{t}$ & 14.806 & 1.509 & $9.807^{*}$ \\
\hline$G D P_{t}^{2}$ & -0.878 & 0.095 & $-9.178^{*}$ \\
\hline$F D I_{t}$ & -0.029 & 0.014 & $-2.023^{* *}$ \\
\hline OIP & 0.027 & 0.014 & $1.870 * * *$ \\
\hline C & -61.451 & 5.953 & $-10.322 *$ \\
\hline$R^{2}$ & \multicolumn{3}{|c|}{0.9678} \\
\hline $\mathrm{Adj}-R^{2}$ & \multicolumn{3}{|c|}{0.963} \\
\hline F-stat & \multicolumn{3}{|c|}{ 293.300* } \\
\hline \multicolumn{4}{|c|}{ Diagnostic analysis } \\
\hline Test & \multicolumn{2}{|c|}{ F-statistic } & P-Value \\
\hline Normal & \multicolumn{2}{|c|}{0.219} & 0.896 \\
\hline Seial & \multicolumn{2}{|c|}{0.761} & 0.476 \\
\hline $\mathrm{ARCH}$ & \multicolumn{2}{|c|}{0.325} & 0.571 \\
\hline Hetero & \multicolumn{2}{|c|}{1.396} & 0.236 \\
\hline CUSUM & \multicolumn{3}{|c|}{ Stable } \\
\hline CUSUM-SQ & \multicolumn{3}{|c|}{ Stable } \\
\hline
\end{tabular}

Note: $*, * *, * * *$ indicates that value is significant at 1,5 , and $10 \%$ threshold, respectively. 
Table 4. Linear ARDL model short-run results

\begin{tabular}{|c|c|c|c|}
\hline \multicolumn{4}{|c|}{ Dependent variable: $C_{t}$} \\
\hline Variable & Coefficient & St. error & T-stat \\
\hline$\Delta G D P_{t}$ & 7.481 & 5.527 & 1.946 \\
\hline$\Delta G D P_{t}^{2}$ & -0.461 & 0.355 & -1.296 \\
\hline$\Delta \mathrm{FDI}_{\mathrm{t}}$ & -0.016 & 0.011 & -1.397 \\
\hline$\triangle \mathrm{OIP}_{\mathrm{t}}$ & 0.004 & 0.024 & 0.179 \\
\hline $\mathrm{ECT}(-1)$ & -0.559 & 0.134 & $-4.176^{*}$ \\
\hline C & 0.018 & 0.009 & 1.946 \\
\hline
\end{tabular}

Note: * refers to the significance at $1 \%$ level.

tion, the CUSUM and CUSUMSQ tests presented in Figure 1, show that the global model is stable which reinforces the robustness of the results.

\subsection{The symmetric analysis results}

The NARDL-related test findings reported in Table 5 indicated the existence of long term relationships across the variables. The coefficient of ECT $(-1)$ is statistically significant and negative indicating that around $64 \%$ of the short-term shortterm unbalance rectified in the long term.

Table 5. F-Bound test for non-linear cointegration

\begin{tabular}{|c|c|c|c|c|}
\hline \multirow{2}{*}{\multicolumn{2}{|c|}{ F-Bound test }} & \multicolumn{3}{|c|}{$\begin{array}{c}\text { Null hypothesis: No levels } \\
\text { relationship }\end{array}$} \\
\hline & & Significance & $\mathrm{I}(0)$ & $I(1)$ \\
\hline \multirow{2}{*}{ F-statistic } & \multirow{2}{*}{6.447} & $10 \%$ & 1.99 & 2.94 \\
\hline & & $5 \%$ & 2.27 & 3.28 \\
\hline \multirow{2}{*}{ k } & \multirow{2}{*}{6} & $2.5 \%$ & 2.55 & 3.61 \\
\hline & & $1 \%$ & 2.88 & 3.99 \\
\hline
\end{tabular}

Regarding the long and short term estimation of the NARDL model, the results show similarities with those found in the ARDL methodology with respect the impact of economic growth on carbon

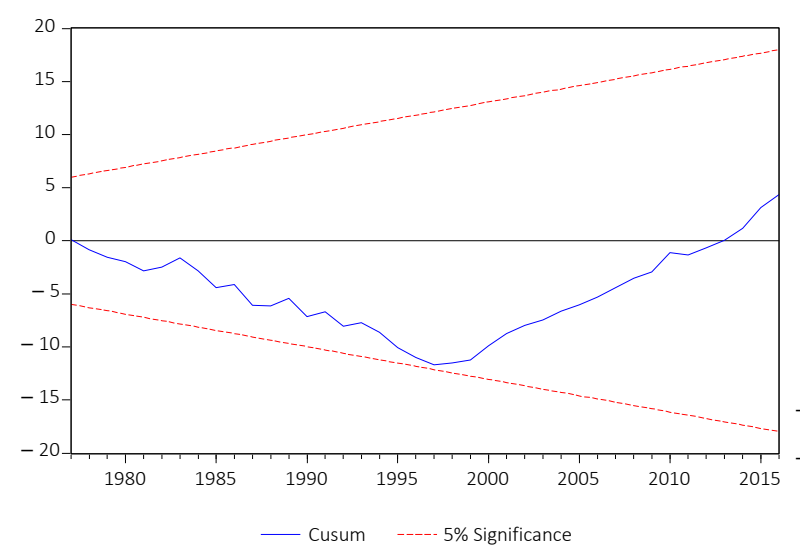

emissions (Tables 6 and 7). Similarly, the NARDL model supports the reversed U-curve over the long term, as does ARDL model.

Table 6. NARDL model long-run results

\begin{tabular}{|c|c|c|c|}
\hline \multicolumn{4}{|c|}{ Dependent variable: $C_{t}$} \\
\hline Variable & Coefficient & St. error & T-stat \\
\hline$G D P_{t}$ & 20.453 & 2.249 & 9.091* \\
\hline$G D P_{t}^{2}$ & -1.270 & 0.140 & $-9.056^{*}$ \\
\hline $\mathrm{FDI}^{+}$ & -0.048 & 0.025 & $-1.955^{* *}$ \\
\hline$F D I-$ & -0.024 & 0.034 & -0.709 \\
\hline $\mathrm{OIP}_{t}^{+}$ & 0.251 & 0.072 & $3.459 *$ \\
\hline OIP & -0.057 & 0.043 & $-1.757^{* *}$ \\
\hline C & -82.058 & 9.080 & $-9.037^{*}$ \\
\hline$R^{2}$ & \multicolumn{3}{|c|}{0.985} \\
\hline Adj- $R^{2}$ & \multicolumn{3}{|c|}{0.978} \\
\hline F-stat & \multicolumn{3}{|c|}{$147.854^{*}$} \\
\hline \multicolumn{4}{|c|}{ Diagnostic analysis } \\
\hline Test & \multicolumn{2}{|c|}{ F-statistic } & P-Value \\
\hline Normal & \multicolumn{2}{|c|}{0.114} & 0.944 \\
\hline Serial & \multicolumn{2}{|c|}{2.164} & 0.135 \\
\hline $\mathrm{ARCH}$ & \multicolumn{2}{|c|}{0.270} & 0.606 \\
\hline Hetero & \multicolumn{2}{|c|}{0.967} & 0.503 \\
\hline CUSUM & \multicolumn{3}{|c|}{ Stable } \\
\hline CUSUM-SQ & \multicolumn{3}{|c|}{ Stable } \\
\hline
\end{tabular}

Note: $*, * *$ indicates that value is significant at 1 and $5 \%$ threshold, respectively.

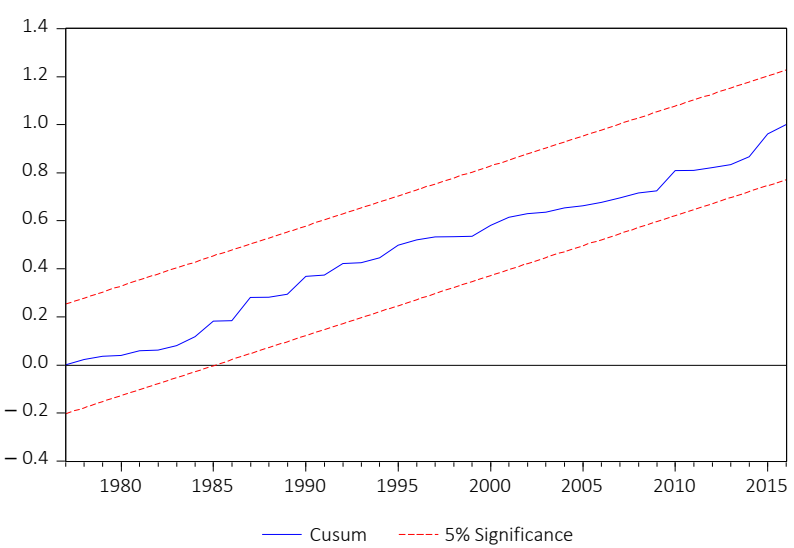

Figure 1. Plots of CUSUM and CUSUMSQ tests 
Table 7. NARDL model short-run results

\begin{tabular}{|c|c|c|c|}
\hline \multicolumn{4}{|c|}{ Dependent variable: $C_{t}$} \\
\hline Variable & Coefficient & St. error & T-stat. \\
\hline$\Delta G D P_{t}$ & 4.579 & 5.368 & 0.852 \\
\hline$\triangle G D P_{t}^{2}$ & -0.285 & 0.344 & -0.828 \\
\hline$\Delta F D I_{t}^{+}$ & -0.008 & 0.015 & -0.557 \\
\hline$\Delta F D I_{t}^{-}$ & 0.004 & 0.028 & 0.153 \\
\hline$\Delta O P_{t}^{+}$ & 0.077 & 0.033 & $2.346^{* *}$ \\
\hline$\Delta O I P_{t}^{-}$ & -0.043 & 0.030 & -1.420 \\
\hline$E C T(-1)$ & -0.647 & 0.128 & $-5.047^{*}$ \\
\hline C & 0.0112 & 0.012 & 0.867 \\
\hline
\end{tabular}

Note: ${ }^{*}$ and ${ }^{* *}, * * *$ refer to the significance at 1 and $5 \%$ level respectively.

As for the asymmetric FDI-CO2 emissions linkage, only the positive shocks in $\mathrm{FDI}\left(\mathrm{FDI}^{+}\right)$cast significant effect as regards carbon emissions which suggests that the Halo hypothesis is valid for the Tunisian economy. However, the absence of an asymmetrical association is verified by the Wald test that evaluates the equality between the coefficients of the two FDI shocks (Table 8), which is quite clear in Figure 2 who presents the dynamic multiplier graph of FDI.

As for the asymmetric crude oil price- $\mathrm{CO} 2$ emissions nexus, the positive shock in the partial sum of crude oil price $\left(O I P^{+}\right)$is significantly positive, meaning that any increase in crude OIP increases
$\mathrm{CO} 2$ emissions in the short term besides the long term, while the negative shock in the partial sum of crude oil price $(O I P)$ is significantly negative, meaning that any decrease in crude OIP decreases in $\mathrm{CO} 2$ emissions in the long-run (Tables 6 and 7). Both the Wald test (Table 8) and the dynamic multiplier graph of OIP (Figure 2) support the asymmetrical association, since it is significant long run.

Table 11 presents equally diagnostics analysis output (lower part) and shows no issue of normality, serial correlation, specification, homoscedasticity, and stability for the studied model (Figure 2).

Table 8. NARDL Wald test

\begin{tabular}{l|c|c|c|c}
\hline \multirow{2}{*}{ Exogenous variable } & \multicolumn{2}{c|}{ Short-run } & \multicolumn{2}{c}{ Long-run } \\
\cline { 2 - 5 } & F-stat. & Prob. & F-stat. & Prob. \\
\hline FDI & 2.268 & 0.143 & 0.427 & 0.518 \\
OIP & 2.123 & 0.156 & 3.997 & $0.055^{*}$ \\
\hline
\end{tabular}

Note: ${ }^{*}$ refers to the significance at $10 \%$ level.
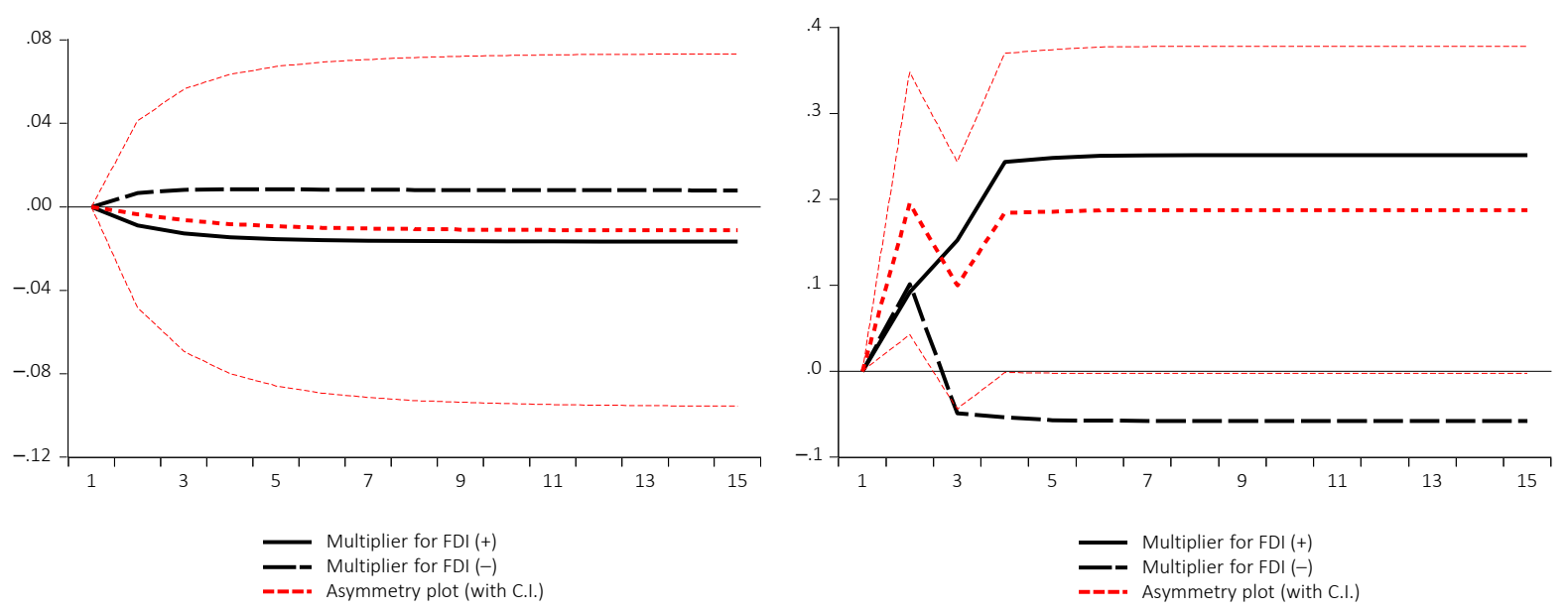

Figure 2. NARDL dynamic multiplier effect graphs 
Table 9. Causality analysis

\begin{tabular}{|c|c|c|c|c|c|}
\hline \multirow{2}{*}{ Independent variables } & \multicolumn{5}{|c|}{ Dependent variable } \\
\hline & $C_{t}$ & $\mathrm{GDP}_{\mathrm{t}}$ & $\mathrm{GDP}_{\mathrm{t}}^{2}$ & $\mathrm{FDI}_{\mathrm{t}}$ & OIP $_{t}$ \\
\hline$C_{t}$ & - & $5.284 * * *$ & $4.812 * * *$ & 4.239 & 0.366 \\
\hline$G D P_{t}$ & $14.833^{*}$ & - & $7.838 * *$ & $6.285^{* * *}$ & 3.839 \\
\hline $\mathrm{GDP}_{\mathrm{t}}^{2}$ & $14.220 *$ & $6.456 * *$ & - & $6.056 * * *$ & 3.444 \\
\hline$F D I_{t}$ & $10.767^{* * *}$ & 1.003 & 1.036 & - & 1.046 \\
\hline OIIP & $9.247 * * *$ & 1.302 & 1.392 & $21.244^{*}$ & - \\
\hline Diagnostic analysis & \multicolumn{2}{|c|}{ F-stat. } & \multicolumn{3}{|c|}{ Prob. } \\
\hline Normality & \multicolumn{2}{|c|}{5.275} & \multicolumn{3}{|c|}{0.872} \\
\hline Heteros. & \multicolumn{2}{|c|}{258.781} & \multicolumn{3}{|c|}{0.677} \\
\hline Serial Corr. & \multicolumn{2}{|c|}{0.888} & \multicolumn{3}{|c|}{0.618} \\
\hline
\end{tabular}

Note: $*, * *, * * *$ indicates that value is significant at 1,5 , and $10 \%$ threshold, respectively.

Table 10. FMOLS and CCR estimates

\begin{tabular}{|c|c|c|c|c|c|c|}
\hline \multicolumn{4}{|c|}{ FMOLS } & \multicolumn{3}{|c|}{ CCR } \\
\hline Variable & Coefficient & St. error & T-Stat. & Coefficient & St. error & T-Stat. \\
\hline GDP & 14.804 & 1.674 & $8.842 *$ & 14.830 & 1.448 & $10.238^{*}$ \\
\hline$Y S Q$ & -0.878 & 0.106 & $-8.280^{*}$ & -0.880 & 0.092 & $-9.528^{*}$ \\
\hline$F D I$ & -0.030 & 0.016 & $-1.923 * * *$ & -0.033 & 0.019 & $-1.735^{* * *}$ \\
\hline OIP & 0.038 & 0.018 & $2.099 * *$ & 0.0380 & 0.017 & $2.131^{* *}$ \\
\hline C & -61.45 & 6.612 & $-9.293^{*}$ & -61.566 & 5.685 & $-10.829 *$ \\
\hline$R^{2}$ & \multicolumn{3}{|c|}{0.966} & \multicolumn{3}{|c|}{0.966} \\
\hline $\operatorname{Adj}-R^{2}$ & \multicolumn{3}{|c|}{0.962} & \multicolumn{3}{|c|}{0.962} \\
\hline
\end{tabular}

Note: $*, * *, * * *$ indicates that value is significant at 1,5 , and $10 \%$ threshold, respectively.

\subsection{Causality analysis results}

Table 9 presents the combine causality outcomes of the long and short-run which has examined by the Block Exogeneity Wald test. The analysis shows a two-way causal direction among GDP per-capita and $\mathrm{CO}_{2}$ emissions, thus supporting the feed-back effect, while a one-way causality running from FDI flow and crude oil price to $\mathrm{CO}_{2}$ emission. This result is consistent with the ARDL and non-linear ARDL evidences. However, no issues occurred during the diagnostic analysis.

\subsection{Robustness check}

To check the robustness of these results, the FMOLS (Fully Modified Ordinary Least Square) and CCR (Canonical Cointegration Regression) are applied to re-estimate the specific model (1). Table 10 presents their results and shows that the results obtained by both FMOLS and CCR are almost in line with the results of long run ARDL estimates in terms of sign and significance which proves the robustness of the model. Moreover, these two estimation techniques affirm that the EKC assumption is well established in the Tunisian economy.

\section{CONCLUSION}

Using annual data covering the 1971-2016 period, this study explores the symmetric and asymmetric association of real GDP per capita, FDI inflow, and crude oil price on CO2 emission of Tunisia. Different from previous studies on Tunisia, this is the first attempt to examine the individual effect of FDI inflow and the crude oil price on $\mathrm{CO} 2$ emissions, while giving more solid evidence for the EKC hypothesis by skipping energy use as an explanatory variable that induces a systematic volatility in the coefficients of the model (Itkonen, 2012). Results from the linear ARDL have suggested a positive effect of crude oil price as regards $\mathrm{CO} 2$ emission in the long term, while the negative and significant component of FDI inflow validates the pollution Halo hypothesis for Tunisia. Whereas, results from the NARDL indicate 
that in the long term, a rise in crude oil price intensifies $\mathrm{CO} 2$ emission, while the decrease in oil price mitigates $\mathrm{CO} 2$ emission in Tunisia. Results from causality analysis divulge that there is feedback effect between economic growth and $\mathrm{CO} 2$ emission, while a one-way causal direction ranges from crude oil price to $\mathrm{CO} 2$ emission. Findings from the robustness check (FMOLS and CCR) reinforce the results of long run ARDL estimates as well as the validity of the EKC hypothesis. Thus, from these findings, some policy recommendations can be drawn.

\section{POLICY RECOMMENDATIONS}

The results of this study warrant attention from Tunisian policymakers. A notable policy implication from the EKC findings is that Tunisia must never back down in its attempts to spur economic expansion, as the results confirm that country can in fact develop from overall carbon emissions through steady income growth. From the standpoint of FDI inflows, the negative effect on carbon emissions should encourage Tunisia to attract more foreign direct investment. For example, preferential taxes, in addition to access to the domestic market, could further attract foreign direct investment.

The result of crude oil prices effect is not surprising because of subsidies on fuel prices on the one hand, and my be also because of the growth in economic activity generated by income from oil export and tax revenues of oil companies on the other hand. Consequently, Tunisian policy makers should review its current fuel pricing policies to insure that national fuel prices reflect international market prices and thereby keeping $\mathrm{CO}_{2}$ emissions under control. Furthermore, it's interestingly that income from oil exports and from the taxation of oil companies could be used to develop clean and environmentally friendly energy sources. The promotion of renewable sources can expand opportunities for cleaner alternatives power and reduce the build-up of greenhouse gases, thus sustains environment.

\section{AUTHOR CONTRIBUTIONS}

Conceptualization: Tarek Ghazouani.

Formal analysis: Tarek Ghazouani.

Investigation: Tarek Ghazouani.

Methodology: Tarek Ghazouani.

Visualization: Tarek Ghazouani.

Writing - original draft: Tarek Ghazouani.

Writing - review \& editing: Tarek Ghazouani.

\section{REFERENCES}

1. Abdouli, M., \& Hammami, S. (2017). Economic growth, FDI inflows and their impact on the environment: an empirical study for the MENA countries. Quality and Quantity, 51, 121-146. https:// doi.org/10.1007/s11135-0150298-6

2. Adu, D. T., \& Denkyirah, E. K. (2019). Economic growth and environmental pollution in West Africa: testing the environmental Kuznets curve hypothesis. Kasetsart Journal of Social Sciences,
40(2), 281-288. https://doi. org/10.1016/j.kjss.2017.12.008

3. Agbanike, T. F., Nwani, C., Uwazie, U. I., Anochiwa, L. I., Onoja T-G. C., \& Ogbonnaya, I. O. (2019). Oil price, energy consumption and carbon dioxide (CO2) emissions: insight into sustainability challenges in Venezuela. Latin American Economic Review, 28, 8. https://doi.org/10.1186/s40503019-0070-8

4. Al-mulali, U. (2012). Factors affecting $\mathrm{CO} 2$ emission in the
Middle East: a panel data analysis. Energy, 44(1), 564-569. https://doi. org/10.1016/j.energy.2012.05.045

5. Al-mulali, U., \& Tang, C. F. (2013). Investigating the validity of pollution haven hypothesis in the gulf cooperation council (GCC) countries. Energy Policy, 60, 813-819. https://doi.org/10.1016/j. enpol.2013.05.055

6. Amri, F. (2017). Intercourse across economic growth, trade and renewable energy consumption in developing and developed 
countries. Renewable and Sustainable Energy Review, 69, 527-534. https://doi.org/10.1016/j. rser.2016.11.230

7. Amri, F. (2018). Carbon dioxide emissions, total factor productivity, ICT, trade, financial development, and energy consumption: testing environmental Kuznets curve hypothesis for Tunisia. Environmental Science and Pollution Research, 25, 3369133701. https://doi.org/10.1007/ s11356-018-3331-1

8. Apergis, N. (2016). Environmental Kuznets curves: new evidence on both panel and country-level $\mathrm{CO} 2$ emissions. Energy Economics, 54, 263-271. https://doi.org/10.1016/j. eneco.2015.12.007

9. Apergis, N., \& Ozturk, I. (2015). Testing environmental Kuznets curve hypothesis in Asian countries. Ecological Indicators, 52, 16-22. https://doi.org/10.1016/j. ecolind.2014.11.026

10. Baek, J. (2016). Do nuclear and renewable energy improve the environment? Empirical evidence from the United States. Ecological Indicators, 66, 352-356. https://doi org/10.1016/j.ecolind.2016.01.059

11. Balsalobre, D., Álvarez, A., \& Cantos, J. M. (2015). Public budgets for energy RD\&D and the effects on energy intensity and pollution levels. Environmental Science and Pollution Research, 22, 4881-4892. https://doi.org/10.1007/s11356014-3121-3

12. Ben Jebli, M., \& Ben Youssef, S. (2015). The environmental Kuznets curve, economic growth, renewable and non-renewable energy, and trade in Tunisia. Renewable and Sustainable Energy Review, 47, 173-185. https://doi. org/10.1016/j.rser.2015.02.049

13. Ben Jebli, M., Ben Youssef, S., \& Ozturk, I. (2016). Testing environmental Kuznets curve hypothesis: the role of renewable and nonrenewable energy consumption and trade in OECD countries. Ecological Indicators, 60, 824-831. https://doi.org/10.1016/j. ecolind.2015.08.031

14. Bölük, G., \& Mert, M. (2015). The renewable energy, growth and environmental Kuznets curve in Turkey: an ARDL approach. Renewable and Sustainable Energy Review, 52, 587-595. https://doi. org/10.1016/j.rser.2015.07.138

15. Boufateh, T. (2019). The environmental Kuznets curve by considering asymmetric oil price shocks: evidence from the top two. Environmental Science and Pollution Research, 26(1), 706-720. https://doi.org/10.1007/s11356018-3641-3

16. Brini, R., Amara, M., \& Jemmali, H. (2017). Renewable energy consumption, International trade, oil price and economic growth inter-linkages: The case of Tunisia. Renewable and Sustainable Energy Reviews, 76, 620-627. https://doi. org/10.1016/j.rser.2017.03.067

17. Chandran, V. G. R., \& Tang, C. F. (2013). The impacts of transport energy consumption, foreign direct investment and income on $\mathrm{CO} 2$ emissions in ASEAN-5 economies. Renewable and Sustainable Energy Reviews, 24, 445-453. https://doi.org/10.1016/j. rser.2013.03.054

18. Cherni, A., \& Jouini, S. E. (2017). An ARDL approach to the $\mathrm{CO} 2$ emissions, renewable energy and economic growth nexus: Tunisian evidence. International Journal of Hydrogen Energy, 42(48), $29056-$ 29066. https://doi.org/10.1016/j. ijhydene.2017.08.072

19. Copeland, B. R., \& Taylor, M. S (1994). North-south trade and the environment. The Quarterly Journal of Economics, 109(3), 755787. Retrieved from http://www. jstor.org/stable/2118421

20. Essandoh, O. K., Islam, M., \& Kakinaka, M. (2020). Linking international trade and foreign direct investment to $\mathrm{CO} 2$ emissions: Any differences between developed and developing countries. Science of The Total Environment, 712, 136437. https://doi.org/10.1016/j. scitotenv.2019.136437

21. Farhani, S., \& Ozturk, I. (2015) Causal relationship between $\mathrm{CO} 2$ emissions, real GDP, energy consumption, financial development, trade openness, and urbanization in Tunisia. Environmental Science and Pollution Research, 22, 1566315676. https://doi.org/10.1007/ s11356-015-4767-1

22. Grossman, G. M., \& Krueger, A. B. (1991). Environmental impacts of a North American free trade agreement (NBER Working Papers No. 3914). Retrieved from https:// www.nber.org/papers/w3914

23. Hakimi, A., \& Hamdi, H. (2016). Trade liberalization, FDI inflows, environmental quality and economic growth: A comparative analysis between Tunisia and Morocco. Renewable and Sustainable Energy Reviews, 58, 1445-1456. https://doi. org/10.1016/j.rser.2015.12.280

24. Haug, A. A., \& Ucal, M. (2019). The role of trade and FDI for CO2 emissions in Turkey: nonlinear relationships. Energy Economics, 81, 297-307. https://doi. org/10.1016/j.eneco.2019.04.006

25. Itkonen, J. V. A. (2012). Problems estimating the carbon Kuznets curve. Energy, 39(1), 274-280. https://doi.org/10.1016/j.energy.2012.01.018

26. Jiang, L., Zhou, H. F., Bai, L., \& Zhou, P. (2018). Does foreign direct investment drive environmental degradation in China? An empirical study based on air quality index from a spatial perspective. Journal of Cleaner Production, 176, 864872. https://doi.org/10.1016/j. jclepro.2017.12.048

27. Kang, Y. K., Zhao, T., \& Yang, Y.Y. (2016). Environmental Kuznets curve for $\mathrm{CO} 2$ emissions in China: A spatial panel data approach. Ecological Indicators, 63, 231239. https://doi.org/10.1016/j. ecolind.2015.12.011

28. Keynes, J. M. (1936). The General Theory of Employment, Interest and Money. London, UK: Macmillan. Retrieved from https://www.files. ethz.ch/isn/125515/1366_KeynesTheoryofEmployment.pdf

29. Kwakwa, P. A, Alhassan, H., \& Aboagye, S. (2018). Environmental Kuznets curve hypothesis in a financial development and 
natural resource extraction context: evidence from Tunisia. Quantitative Finance and Economics, 2(4), 981-1000. Retrieved from https://www. researchgate.net/publication/329777135_Environmental_ Kuznets_curve_hypothesis_in_a financial_development_and_natural_resource_extraction_context_ evidence_from_Tunisia

30. Lee, J. W. (2013). The contribution of foreign direct investment to clean energy use, carbon emissions and economic growth. Energy Policy, 55, 483-489. https://doi.org/10.1016/j.enpol.2012.12.039

31. Mahmood, H., Maalel, N., \& Zarrad, O. (2019). Trade Openness and CO2 Emissions: Evidence from Tunisia. Sustainability, 11(12), 3295. https://doi.org/10.3390/ su11123295

32. Malik, M. Y., Latif, K., Khan, Z., Butt, H. D, Hussain, M., \& Nadeem, M. A. (2020). Symmetric and Asymmetric Impact of Oil Price, FDI and Economic Growth on Carbon Emission in Pakistan: Evidence from ARDL and NonLinear ARDL Approach. Science of the Total Environment, 726, 138421. https://doi.org/10.1016/j. scitotenv.2020.138421

33. Mensah, I. A., Suna, M., Gaoa, C., Omari-Sasub, A. Y., Zhuc, D., Ampimaha, B. C., \& Quarcoo, A. (2019). Analysis on the nexus of economic growth, fossil fuel energy consumption, $\mathrm{CO} 2$ emissions and oil price in Africa based on a PMG panel ARDL approach. Journal of Cleaner Production, 228, 161174. https://doi.org/10.1016/j. jclepro.2019.04.281

34. Nicolli, F., \& Vona, F. (2019). Energy market liberalization and renewable energy policies in OECD countries. Energy Policy, 128, 853-867. https://doi. org/10.1016/j.enpol.2019.01.018

35. Nwani, C. (2017). Causal relationship between crude oil price, energy consumption and carbon dioxide (CO2) emissions in Ecuador. OPEC Energy Review,
41(3), 201-225. https://doi. org/10.1111/opec.12102

36. Omri, A., Nguyen, D. K., \& Rault, C. (2014). Causal interactions between $\mathrm{CO} 2$ emissions, FDI, and economic growth: evidence from dynamic simultaneous-equation models. Economic Modelling, 42, 382-389. https://doi.org/10.1016/j. econmod.2014.07.026

37. Pata, U. K. (2018). The influence of coal and noncarbohydrate energy consumption on $\mathrm{CO} 2$ emissions: revisiting the environmental Kuznets curve hypothesis for Turkey. Energy, 160, 1115-1123. https://doi. org/10.1016/j.energy.2018.07.095

38. Pesaran, M. H., Shin, Y., \& Smith, R. J. (2001). Bounds testing approaches to the analysis of level relationships. Journal of Applied Econometrics, 16(3), 289-326. https://doi.org/10.1002/jae.616

39. Shahbaz, M., \& Sinha, A. (2019). Environmental Kuznets curve for $\mathrm{CO} 2$ emissions: a literature survey. Journal of Economic Studies, 46(1), 106-168. https://doi.org/10.1108/ JES-09-2017-0249

40. Shahbaz, M., Balsalobre-Lorente, D., \& Sinha, A. (2019). Foreign direct Investment-CO2 emissions nexus in Middle East and North African countries: Importance of biomass energy consumption. Journal of Cleaner Production, 217, 603-614. https://doi.org/10.1016/j. jclepro.2019.01.282

41. Shahbaz, M., Khraief, N., Uddin, G. S., \& Ozturk, I. (2014). Environmental Kuznets curve in an open economy: A bounds testing and causality analysis for Tunisia. Renewable and Sustainable Energy Reviews, 34, 325-336. https://doi.org/10.1016/j. rser.2014.03.022

42. Shin, Y., Yu, B., \& GreenwoodNimmo, M. (2014). Modelling asymmetric cointegration and dynamic multipliers in a nonlinear ARDL framework. In R. C. Sickles, \& W. C. Horrace (Eds.), Festschrift in Honor of Peter Schmidt: Econometric Methods and Applications (pp. 281-314). Springer, New York. https://doi. org/10.1007/978-1-4899-8008-3_9
43. Stern, D. I. (2011). The role of energy in economic growth. Annals of the New York Academy of Sciences, 1219(1), 26-51. https://doi.org/10.1111/j.17496632.2010.05921.x

44. Sturm, M., Gurtner, F. J., \& Gonzalez, J. (2009). Fiscal policy challenges in oil-exporting countries- A review of key issues (ECB Occasional Paper Series No.104). Frankfurt, Germany. Retrieved from https://papers.ssrn. com/sol3/papers.cfm?abstract_ $\mathrm{id}=1325245$

45. Sung, B., Song, W. Y., \& Park, S. D. (2018). How foreign direct investment affects $\mathrm{CO} 2$ emission levels in the Chinese manufacturing industry: evidence from panel data. Economic System, 42(2), 320-331. https://doi. org/10.1016/j.ecosys.2017.06.002

46. Usman, O., Iorember, P. T., \& Olanipekun, I. O. (2019). Revisiting the environmental Kuznets curve (EKC) hypothesis in India: the effects of energy consumption and democracy. Environmental Science and Pollution Research, 26(13), 1339013400. https://doi.org/10.1007/ s11356-019-04696-Z

47. Vielle, M., \& Viguier, L. (2007). On the climate change effects of high oil prices. Energy Policy, 35(2), 844-849. https://doi. org/10.1016/j.enpol.2006.03.022

48. World Bank Indicator. (2019). World Development Indicators. Retrieved from https://datacatalog. worldbank.org/dataset/worlddevelopmentindicators

49. Zhang, C., \& Zhou, X. (2016). Does foreign direct investment lead to lower $\mathrm{CO}$ emissions? Evidence from a regional analysis in China. Renewable and Sustainable Energy Reviews, 58, 943-951. https://doi.org/10.1016/j. rser.2015.12.226 


\section{APPENDIX A}
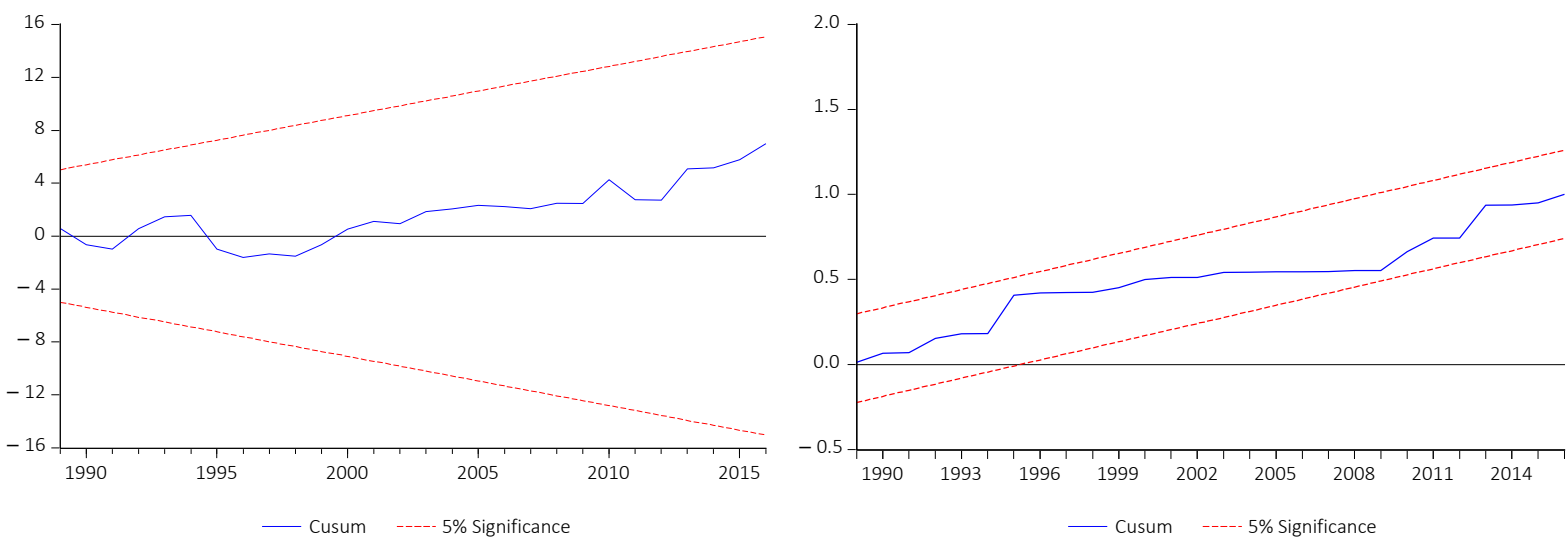

Figure A1. Plots of CUSUM and CUSUMSQ tests (NARDL model) 